\title{
Cerebral-perfusion Reserve after Carotid-artery Stenting: Relationship with Power Spectrum of Electroencephalography
}

Da-hye Jeong ${ }^{1}$, Seokwon Jung ${ }^{1}$, Byeonggeun Kwak ${ }^{1}$, Young-Soo Kim ${ }^{1,2}$, Soo-kyoung Kim², and Oh-Young Kwon ${ }^{1,2}$

\section{경동맥스텐트삽입술 후의 뇌관류예비능: 뇌파파워스펙트럼과의 연관성}

정다혜 ${ }^{1}$, 정석원 $^{1}$, 곽병근 $^{1}$, 김영수 $^{1,2}$, 김수경 ${ }^{1,2}$, 권오영 ${ }^{1,2}$

${ }^{1}$ 경상대학교 의학전문대학원 신경과학교실, ${ }^{2}$ 경상대학교 건강과학연구원

\begin{abstract}
Carotid-artery stenosis may reduce cerebral perfusion, and affect cerebral neuronal activities. We examined the question of whether the recovery of cerebral-perfusion reserve after carotid-artery stenting (CAS) can affect the EEG power-spectrum. Nineteen candidates for CAS were initially recruited. Subtraction imaging of single photon emissary computerized tomography (SPECT) and an electroencephalogram (EEG) were taken twice, before and 1 month after CAS. At each time point, the EEGs were recorded before and after injection of acetazolamide (pre-ACZ EEG and post-ACZ EEG). Finally, 7 patients were enrolled after exclusion of incomplete studies. We obtained the spectral ratio (SR) of each hemisphere. SR was defined as the divided value of the power-spectrum sum of fast activities by that of slow activities. The power-spectrum values between hemispheres were compared using the inter-hemispheric index of spectral ratio (IHISR), and we examined the correlation between the power-spectrum and the cerebral-perfusion reserve. Cerebral-perfusion reserve improved after CAS on the stent side in 6 of 7 patients. In 3 patients with unilateral carotid-artery stenosis, CAS increased SR on the pre-ACZ EEGs, and IHISR on the post-ACZ EEGs. The increases of SR and IHISR were concordant with the increment of cerebral-perfusion reserve. In contrast, the results in the other patients with bilateral stenosis showed complex patterns. The SR of pre-ACZ EEGs and IHISR of post-ACZ EEGs may be useful electrophysiological markers for the blood-flow reserve after CAS in patients with unilateral carotid-artery stenosis, but not in those with bilateral stenosis.
\end{abstract}

Keywords: Carotid stenosis, Stents, Electroencephalography, Spectrum analysis

This is an Open Access article distributed under the terms of the Creative Commons Attribution Non-Commercial License (http://creativecommons.org/licenses/by-nc/4.0) which permits unrestricted non-commercial use, distribution, and reproduction in any medium, provided the original work is properly cited.

Copyright @ 2016 The Korean Society for Clinical Laboratory Science. All rights reserved.
Corresponding author: Oh-Young Kwon Department of Neurology, Gyeongsang National University Hospital, Gyeongsang National University School of Medicine, 816-15 Jinjudae-ro, Jinju 52727, Korea Tel: 82-55-750-8288 Fax: 82-55-750-1709 E-mail: mnkwon21@daum.net

Co-Corresponding author: Seokwon Jung Department of Neurology, Gyeongsang National University School of Medicine, Jinju 52727, Korea

Tel: 82-55-750-8288

Fax: 82-55-750-1709

E-mail: swjeong3@naver.com

Received: April 21, 2016 Revised: May 11, 2016 Accepted: May 11, 2016

\section{서 론}

뇌조직이 생존하려면 뇌혈류가 적절하게 유지되어야 한다. 뇌혈
관에 존재하는 다수의 곁순환경로는 뇌혈류를 유지하는데 도움을 준다. 이러한 곁순환경로들은 혈관의 상태가 좋지 않을 때 국소뇌 혈류(regional cerebral blood flow, rCBF)를 증가시킨다. 이렇게 
부족한 혈류를 증가시키는 능력이 뇌관류예비능(cerebral perfusion reserve)이다[1]. 뇌관류예비능은 뇌의 자동조절력에 의해 혈관이 확장하는 정도에 의해 결정된다. 뇌혈류에 문제가 생기면 생리적 범위 안에서는 뇌가 자동으로 조절하여 혈관을 확장시킨다. 혈관이 확장되면 혈관의 저항이 감소되어 뇌혈류를 정상적으로 유지할 수 있다. 만성적으로 혈관이 협착되거나 폐색된 환자에서는 뇌혈류가 줄어들지만 뇌관류예비능이 적절하면 그런대로 뇌혈류가 보상되 어 공급된다. 따라서 뇌관류예비능은 만성뇌혈관질환이 있는 환자 에서 예후를 결정할 수 있는 주요한 인자이다[2-4]. 아세타졸라마 이드 투여검사(acetazolamide challenge test)는 뇌관류예비능을 측정하는 검사이다. 이 검사에서는 뇌혈류를 두 번 측정하여 뇌관 류예비능을 평가한다. 처음에는 기본 상태에서 환자의 뇌혈류를 측 정하고 두 번째는 아세타졸라마이드와 같은 혈관확장제를 투여한 후에 측정한다[5].

뇌혈류의 변화를 간접적으로 관찰할 때 뇌파를 사용하기도 한 다. 뇌의 일부분에 혈류량이 감소하여 보상작용의 한계를 넘으면 해당부위에서 뇌파변화가 발생한다. 뇌혈류가 심하게 감소하여 신 경활동이 정지되면 배경뇌파는 서파화 혹은 평탄화 된다[6]. 따라 서 뇌파를 이용하여 뇌의 혈액공급상태를 간접적으로 추정하기도 한다. 경동맥내막절제술(carotid endarterectomy)을 하는 과정에 뇌혈류를 감시하기 위해 뇌파를 활용하는 것이 그 예이다[7]. 특히 디지털뇌파가 보편화된 이후로는 뇌파의 디지털데이터를 분석하 여 뇌혈류 변화에 의한 뇌파의 변화를 객관적으로 관찰을 할 수 있 게 되었다. 파워스펙트럼분석은 빠른푸리에변환(fast Fourier transformation)을 이용하여 시간의 요소를 없애고 뇌파에 관찰되 는 파동을 주파수 영역에 따른 파워스펙트럼의 정량적 수치로 제시 한다[8].

뇌파를 이용한 이전의 연구들은 주로 경동맥내막절제술을 하는 경우에서 뇌혈류량과 뇌파의 관계를 관찰하였다. 경동맥내막절제 술을 하는 도중에 경동맥을 결찰하고 뇌혈류가 감소할 때 뇌파변화 를 관찰하였다[6,9]. 경동맥을 결찰한 쪽의 반구에 배경파의 진폭 이 감소되거나 델타서파가 증가하였다[10]. 경동맥폐쇄가 있는 환 자에서의 뇌자기공명영상의 관류영상을 통해서 혈류량의 변화를 관찰한 연구도 있었다. 이 연구에서 한쪽 경동맥만 폐쇄된 환자의 경우 같은 쪽 뇌혈류가 백질과 회백질 모두에서 떨어지는 경향을 보여주었다[11].

경동맥스텐트삽입술은 뇌혈류양을 증가시킨다[12]. 이 변화가 뇌파에 미치는 영향을 조사한 연구는 드물다. 뇌파검사는 임상에서 비교적 쉽게 접근할 수 있고 검사방법도 어렵지 않으므로 뇌혈류양 의 변화를 뇌파로 판단할 수 있다면 시술 후 뇌의 혈역학적 변화를 평가는 수단으로 유용할 것이다. 저자들은 본 연구에서는 경동맥스 텐트삽입술(carotid artery stenting)을 시술 받은 환자에서 1개월 의 시간간격을 둔 두 번의 시점에서 뇌단일광자방출전산화단층촬 영-감산영상(brain single photon emission computed tomography-substraction imaging, 뇌SPECT-감산영상)을 촬영하고 뇌파검사를 하였다. 이 자료를 이용하여 경동맥스텐트삽입술 이후 뇌관류예비능을 평가하기 위해 뇌파파워스펙트럼의 변화를 관찰 하여 이들 사이의 상관관계를 파악하고자 하였다.

\section{대상 및 방법}

\section{1. 연구대상}

경동맥협착을 교정하기 위해 경동맥스텐트삽입술을 시행한 일 련의 환자 19명을 대상으로 하였다. 경동맥에 스텐트를 넣기 전 상 태의 뇌혈류와 뇌파를 관찰하기 위해 뇌SPECT-감산영상과 뇌파 를 검사하였으며, 추적관찰 약 1 개월 후의 시점에서 다시 뇌 $\mathrm{SPECT}$-감산영상과 뇌파를 검사하여 두 시점 사이의 변화를 관찰 하였다. 모집된 19명의 환자 중 경동맥스텐트를 삽입한 후 외래추 적관찰이 되지 않은 9명의 환자는 제외되었으며 뇌파에 아티팩트 가 많아 파워스펙트럼분석을 위한 뇌파구간의 선택이 어려웠던 3 명의 환자도 제외 되었다. 최종적으로 7 명의 환자가 이 연구의 대상 이 되었다(Table 1).

대상환자 7명 중 6명은 남성이었고 1명은 여성이었으며 평균나 이는 69세(60 79세)였다. 대상환자 모두가 한 가지 이상의 심혈 관 위험인자를 가지고 있었다. 고혈압만 있었던 환자는 4 명이었다. 1 명은 고혈압, 당뇨병과 고지혈증을 진단받았고, 1 명은 고혈압과 당뇨병을 함께 진단받았으며 뇌경색의 기왕력도 있었다. 나머지 1 명은 당뇨병이 있었으며 흡연력이 있었다. 대상환자 7명 중 5명의 환자가 아스피린과 클로피도그렐을 함께 복용하고 있었고 나머지 2 명의 환자는 아스피린, 클로피도그렐과 실로스타졸을 함께 복용 하고 있었다.

경동맥협착과 관련된 임상증상이 있었던 증상경동맥협착증환 자는 6명(85.7\%)이었고 관련된 임상증상이 없는 무증상경동맥협 착증환자는 1 명 $(14.3 \%)$ 이었다. 증상경동맥협착증환자 6 명은 일 과뇌허혈이 있었던 2명, 반신마비 1명, 일과실명 2 명과 실명 1 명이 었다. 증상경동맥협착증환자 중 뇌자기공명영상에서 급성뇌경색 병변이 관찰된 환자는 3 명이었다.

한쪽 경동맥에만 협착이 있고 반대쪽 경동맥은 정상이었던 환자 는 '한쪽협착'이라고 하고 경동맥스텐트를 삽입한 쪽뿐만 아니라 반대쪽 경동맥에도 협착이나 폐색을 가진 환자는 '양쪽협착'으로 분류하였다. 한쪽협착 환자는 3 명(42.9\%)이었고, 양쪽협착 환자는 4 명(51.9\%)이었다. 한쪽협착 환자 중 2명은 오른쪽에 협착이 있었 
Table 1. Clinical information and demographic features

\begin{tabular}{|c|c|c|c|c|c|c|c|c|}
\hline Patient & $\begin{array}{l}\text { Sex } \\
\text { /Age }\end{array}$ & $\begin{array}{l}\text { Underlying } \\
\text { risk factors }\end{array}$ & $\begin{array}{l}\text { Neurologic } \\
\text { Symptom }\end{array}$ & $\begin{array}{c}\text { Acute } \\
\text { infarction in } \\
\text { Brain MRI }\end{array}$ & $\begin{array}{l}\text { Stenting } \\
\text { site }\end{array}$ & $\begin{array}{l}\text { Severity of } \\
\text { stenosis }\end{array}$ & $\begin{array}{l}\text { Contralateral } \\
\text { steno-occlusive } \\
\text { lesions }\end{array}$ & Medications \\
\hline 2 & $M / 73$ & Hypertension & + & - & Left ICA & $>90 \%$ & None & Aspirn, Clopidogrel \\
\hline 3 & $M / 60$ & Hypertension & + & - & Right ICA & $>80 \%$ & None & Aspirin, Clopidogrel \\
\hline 5 & $M / 68$ & $\begin{array}{l}\text { Hypertension, } \\
\text { DM, Hx* }\end{array}$ & + & + & Left ICA & $>80 \%$ & Rt CCA occlusion & $\begin{array}{l}\text { Aspirin, Clopidogrel, } \\
\text { Cilostazol }\end{array}$ \\
\hline 7 & $M / 79$ & Hypertension & - & - & Left ICA & $>70 \%$ & Rt ICA occlusion & $\begin{array}{l}\text { Aspirin, Clopidogrel, } \\
\text { Cilostazol }\end{array}$ \\
\hline 10 & $M / 65$ & $\begin{array}{l}\text { Hypertension, DM, } \\
\text { Hyperlipidemia }\end{array}$ & + & - & Right ICA & $>80 \%$ & Lt ICA occlusion & $\begin{array}{l}\text { Aspirin, } \\
\text { Clopidogrel }\end{array}$ \\
\hline 13 & $\mathrm{~F} / 72$ & Hypertension & + & + & Right ICA & $>70 \%$ & None & Aspirin, Clopidogrel \\
\hline 16 & $M / 66$ & DM, Smoking & + & + & Right ICA & $>70 \%$ & $\begin{array}{l}\text { Lt MCA occlusion, Lt } \\
\text { ICA stenosis }(50 \%)\end{array}$ & Aspirin, Clopidogrel \\
\hline
\end{tabular}

*Previous stroke history.

Abbreviation: ICA, internal carotid artery; DM, diabetes mellitus; CCA, common carotid artery; MCA, middle cerebral artery.

으며 1명은 왼쪽에 협착이 있었다. 양쪽협착 4명중 2명은 오른쪽에 시술대상인 경동맥협착이 있었고, 2명은 왼쪽에 있었다. 7명의 환 자 중 4명에서 오른쪽 경동맥에 시술하였고 3명에서 왼쪽 경동맥 에 시술하였다. 시술한 경동맥의 반대쪽경동맥에 협착 또는 폐색을 가진 환자 4명에서 시술한 쪽의 이상 부위와 정도에 따라 내경동맥 폐쇄가 2명, 총경동맥폐쇄가 1명, 그리고 내경동맥이 협착되고 중 간대뇌동맥이 폐쇄되었던 1명이 있었다. 전체 환자에서 시술한 쪽 경동맥의 협착 정도는 증상경동맥협착환자 6명에서 70 90\%로 다양했고, 무증상경동맥협착환자 1명에서는 $70 \%$ 을 나타내었다 (Table 1).

\section{2. 연구 방법}

\section{1) 경동맥협착의 평가와 경동맥스텐트삽입술}

컴퓨터단층촬영혈관조영술과 고식혈관조영술의 결과에 NASCET 방법(North American Symptomatic Carotid Endarterectomy Trial) [13]을 적용하여 경동맥 협착 정도를 평가하였다. 뇌컴퓨터 단층촬영혈관조영술은 Light Speed VCT 64채널 컴퓨터단층촬영 기(GE Medical Systems, Milwaukee, USA)를 이용하였고, 고식혈 관조영술은 Allura FD20 디지털혈관조영촬영장치(Philips Medical System, Best, Netherlands)를 이용하였다, 증상경동맥협착환자 는 $70 \%$ 이상의 협착이 있을 때 경동맥스텐트삽입술을 하였고, 무 증상경동맥협착환자는 $90 \%$ 이상의 협착이 있을 때 시술하였다. 모 든 증례는 숙련된 신경영상의학과 전문의 한 명(DS Choi)이 시술 하였다. 시술과정에서는 FilterWire EZTM 색전방지기구(Boston Scientific, Natick, MA, USA)를 사용하였다. 시술하는 중이나 직 후에 합병증이 발생한 증례는 없었고, 1 달간의 추적관찰 기간 동안 에 경동맥협착과 관련된 새로운 증상이 발생한 환자도 없었다.

\section{2) 뇌SPECT-감산영상}

경동맥스텐트를 삽입하기 직전에 뇌SPECT-감산영상을 얻었고 시술하고 나서 약 1 개월이 경과한 후에 다시 뇌SPECT-감산영상을 얻어 두 영상을 비교하였다. SPECT (Siemens, Illinois, USA)를 사 용하였다, 한번의 뇌SPECT-감산영상을 얻기 위해 아세타졸라마 이드(acetazolamide)부하 전과 후, 두번의 뇌SPECT를 촬영하였 다. $99 \mathrm{mTc}-\mathrm{HMPAO} 740 \mathrm{MBq}$ 를 정주하고 5 분이 경과한 후에 첫 번 째 뇌SPECT를 20분간 촬영하였다. $99 \mathrm{mTc}-\mathrm{HMPAO} 740 \mathrm{MBq}$ 주 입하고 나서 13 분이 경과한 시점에서 아세타졸라마이드 $1 \mathrm{~g}$ 을 정 주하여 아세타졸라마이드 부하 후 뇌SPECT 촬영을 준비하였다. 첫 번째 촬영이 끝나면 다시 $99 \mathrm{mTc}-\mathrm{HMPAO} 740 \mathrm{MBq}$ 를 투여하고 5 분이 경과한 후에 두 번째 뇌SPECT를 20 분간 촬영하였다. 두 번 째 촬영에서 첫 번째 촬영을 감산하여 뇌SPECT-감산영상을 얻었다.

\section{3) 뇌파검사와 파워스펙트럼분석}

경동맥스텐트를 삽입하기 직전과 삽입하고 나서 약 1 개월이 경 과한 후에 뇌파를 기록하였다. 각 시점에서 아세타졸라마이드부 하-뇌SPECT검사를 한 직후에 뇌파실로 환자를 이동하여 뇌파를 기록하였으며 최소 30분 이상 기록하였다. 국제 10 20 체계 (international 10 20 system)에 따른 기본전극(Fp1/2, F7/8, $\mathrm{T} 7 / 8, \mathrm{P} 7 / 8, \mathrm{~F} 3 / 4, \mathrm{C} 3 / 4, \mathrm{P} 3 / 4, \mathrm{O} 1 / 2, \mathrm{Fz}, \mathrm{Cz}, \mathrm{Pz})$ 에 측두밑전극 (F9/10, T9/10, P9/10)을 포함하여 총25개의 전극을 부착하여 뇌 파를 기록하였다. Comet EEG machine 32채널 디지털뇌파기 (Grass-telefactor, Westwarwick, USA)를 이용하였으며 숙련된 뇌파기사 1 인(S Jung)에 의해 기록되었다. 환자는 눈을 감고 누워 충분히 이완된 상태에서 검사가 진행되었다. 검사 중 눈을 뜨고 감 았을 때의 뇌파의 변화를 관찰하였으며 과호흡과 광자극을 통한 유 발검사를 하였다. 검사 중 환자들은 충분히 협조해 주었다. 
뇌파분석은 파워스펙트럼분석방법을 이용하였다. 대상환자의 뇌파에서 5 초의 지속시간을 가지는 뇌파절편 여섯 개를 선택하였 다. 뇌파절편은 아티팩트가 없고 후두부에는 알파파가 관찰되는 각 성상태의 배경파에서 선택하였다(Fig. 2). 선택한 뇌파절편들은 $\mathrm{BESA}$ 소프트웨어 5.3 (BESA GmbH, Germany)의 자료처리모듈 을 이용하여 파워스펙트럼분석을 하였다. 주파수(Frequency)에 따라 4 개의 주파수대역(band)의 범위를 설정하였는데 델타대역은 $0.5 \sim 4 \mathrm{~Hz}$, 세타대역은 $4 \sim 8 \mathrm{~Hz}$, 알파대역은 8 13 Hz, 베타대역 은 13 30 Hz로 정하였다. 머리의 중앙선에 위치하는 $\mathrm{Fz}, \mathrm{Cz}$ 과 $\mathrm{Pz}$ 전극은 분석에서 제외하였다. 나머지 전극에서 오른쪽 반구에 위치 하는 모든 전극(Fp2, F8, T8, P8, F4, C4, P4, O2, F10, T10, P10)의 파워스펙트럼을 합산하여 오른쪽 반구의 주파수대역에 따른 파워 스펙트럼값을 얻었다. 왼쪽 반구에 위치하는 모든 전극(Fp1, F7, T7, P7, F3, C3, P3, O1, F9, T9, P9)의 파워스펙트럼도 모두 합산 하여 왼쪽 반구의 주파수대역에 따른 파워스펙트럼 값을 얻었다. 한쪽 반구에서 빠른파형군(알파주파수대역과 베타주파수대역)과 느린파형군(델타주파수대역과 세타주파수대역)의 파워스펙트럼 값의 상대적 비인 파워스펙트럼비(spectral ratio, 스펙트럼비)를

\section{A Pre-acetazolamide}

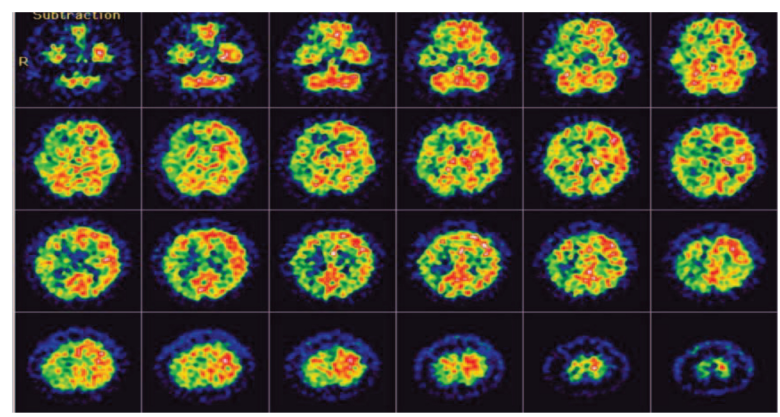

B Post-acetazolamide

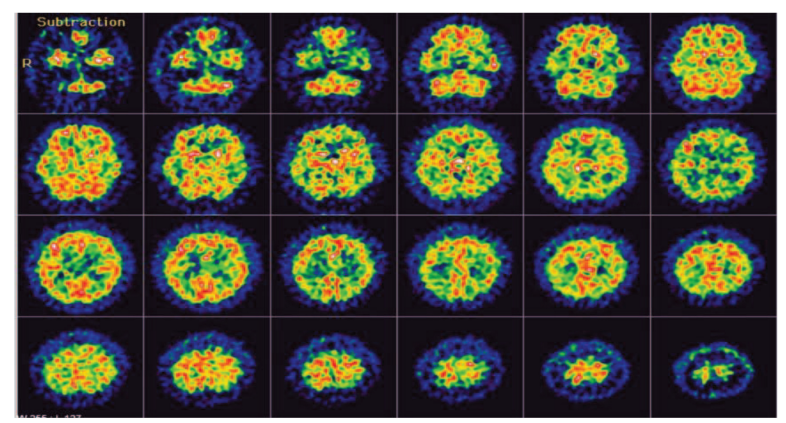

Fig. 1. Subtraction single-photon emission computed tomography (SPECT) images of a patient with unilateral carotid stenosis on the left side. Blood flow reserve remarkably decreased in the left than the contralateral hemisphere on the pre-acetazolamide SPECT (A). The blood flow reserve recovered on the post-acetazolamide SPECT (B).
다음과 같이 정의하여 각 대상환자에서 왼쪽 반구와 오른쪽 반구에 서 각각 그 수치를 구하였다.
Spectral ratio $=(\alpha+\beta) /(\delta+\theta)$
$\alpha$ : sum of alpha-power spectrum
$\beta$ : sum of beta-power spectrum
$\delta$ : sum of delta-power spectrum
$\theta$ : sum of theta-power spectrum

경동맥스텐트를 시술한 쪽 반구와 반대쪽 반구의 파워스펙트럼 비를 비교하기 위해서 반구간스펙트럼인덱스(interhemispheric index of spectra ratio, 반구인덱스)를 정의하였다. 뇌의 혈역학이 다양한 점을 고려하면 파워스펙트럼비의 단순한 증감만으로 뇌의 혈역학적 변화를 알기 어려우므로 반대쪽 뇌반구의 상황을 고려한 반구인덱스가 필요하였다. 이 인덱스는 경동맥스텐트를 시술한쪽 반구의 파워스펙트럼의 수치를 양쪽 대뇌반구의 파워스펙트럼을 더한 값으로 나누어 계산하였다. 양쪽 반구의 파워스펙트럼비가 동 일하면 반구인덱스가 0.5 이고, 경동맥스텐트를 시술한 쪽 뇌반구 의 파워스펙트럼비가 반대쪽 반구의 파워스펙트럼비에 비해 빠른 파형군이 상대적으로 많거나 느린파형군이 적으면 이 수치는 0.5 보다 커진다.

Interhemispheric index of spectral ratio=(SR of hemisphere with CAS)/(Sum of SR of both hemispheres)

SR: spectral ratio

CAS: carotid-artery stenting

경동맥스텐트삽입술로 인한 파워스펙트럼의 변화를 수치화하 기 위해서 시술 후에서 시술 전의 반구인덱스를 뺀 반구인덱스차이 ( $\triangle \mathrm{IHISR}$ )를 다음과 같이 백분율로 나타내었다.

$\Delta$ IHISR=(IHISR just before CAS - IHISR 1 month after CAS) $\times 100$

CAS: carotid-artery stenting

IHISR: interhemispheric index of spectral ratio

AIHISR: percent difference of IHISRs between IHISR 1 month after CAS and IHISR just before CAS 

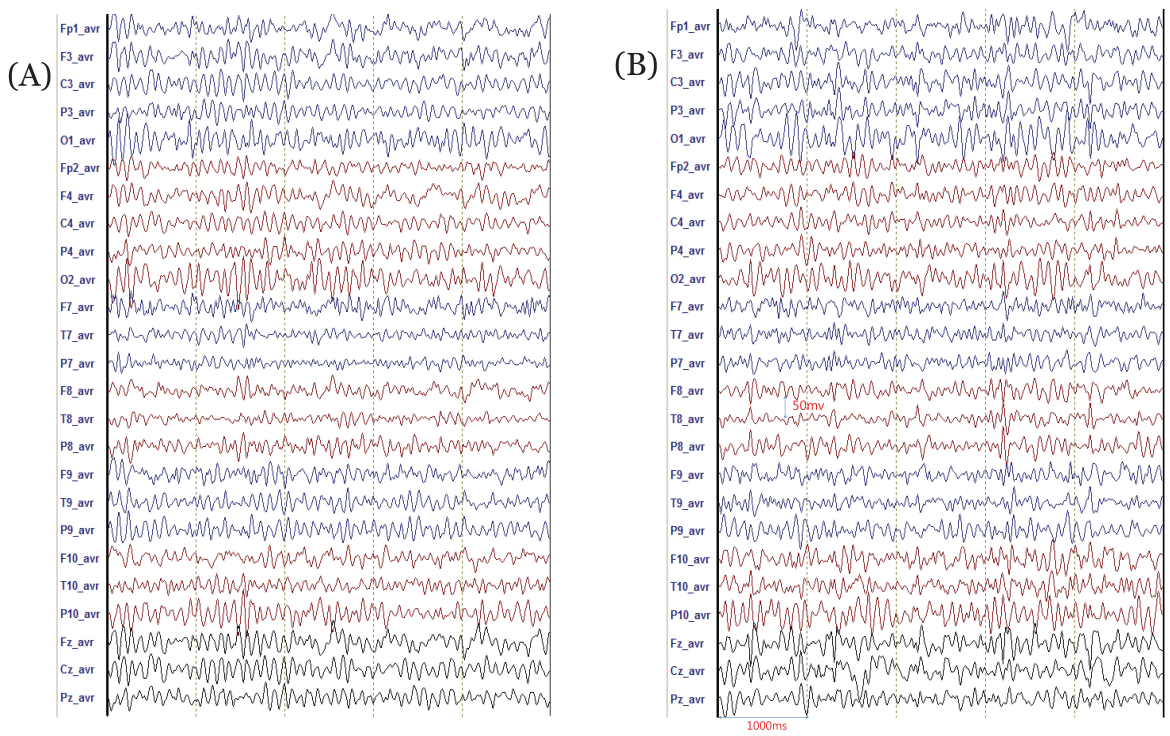

Fig. 2. Selected segments of electroencephalography (EEG) for a power spectrum analysis. These EEG segments were obtained after the carotid-artery stenting on the right side in an enrolled patient. Two 5-sec artifact free segments were selected during the awake state before (A) and after acetazolamide injection (B). In spite that we could hardly see the difference of EEG activities between the two segments, the results of power spectrum analysis reflected the changes of cerebral-perfusion reserve.

Table 2. Spectral ratios in the patients with unilateral stenosis: correlation with the increases of blood-flow reserve in the hemisphere with carotid-artery stenting

\begin{tabular}{|c|c|c|c|c|c|c|}
\hline \multirow{2}{*}{ Patient number } & \multirow{2}{*}{$\begin{array}{l}\text { EEGs according to } \\
\text { ACZ injection }\end{array}$} & \multicolumn{2}{|c|}{ SR of $C A S-H$} & \multicolumn{2}{|c|}{ SR of $\mathrm{No}^{-\mathrm{H}}$} & \multirow{2}{*}{$\begin{array}{l}\text { Increase of blood-flow } \\
\text { reserve in CAS-H }\end{array}$} \\
\hline & & Pre-stent* & Post-stent $^{\dagger}$ & Pre-stent & Post-stent & \\
\hline \multirow[t]{2}{*}{2} & Pre-ACZ ${ }^{\dagger}$ & 2.93 & 3.07 & 3.12 & 3.72 & Yes \\
\hline & Post-ACZ ${ }^{\S}$ & 2.07 & 3.39 & 2.44 & 3.40 & \\
\hline \multirow[t]{2}{*}{3} & Pre-ACZ & 2.12 & 2.27 & 2.64 & 2.26 & Yes \\
\hline & Post-ACZ & 3.01 & 1.49 & 3.23 & 1.47 & \\
\hline \multirow[t]{2}{*}{13} & Pre-ACZ & 1.25 & 4.46 & 3.66 & 4.86 & Yes \\
\hline & Post-ACZ & 2.22 & 2.83 & 5.41 & 3.54 & \\
\hline
\end{tabular}

*Baseline time point.

${ }^{\dagger} 1$ month after carotid-artery stenting.

${ }^{\ddagger} \mathrm{EEG}$ taken before the injection of acetazolamide.

${ }^{\S}$ EEG taken after the injection of acetazolamide.

Abbreviation: EEG, electroencephalogram; ACZ, acetazolamide; SR, spectral ratio; $\mathrm{CAS}-\mathrm{H}$, hemisphere with carotid-artery stenting; No-H, hemisphere without carotid-artery stenting.

\section{결 과}

\section{1. 뇌관류예비능의 변화}

7 명의 환자 중 1 명을 제외한 6 명의 환자에서 경동맥스텐트삽입 술을 한 후에 시술한 쪽 반구의 뇌혈류예비능이 증가되어 있는 것 을 뇌SPECT-감산영상을 통해 확인할 수 있었다(Fig. 1). 한쪽에만 내경동맥협착이 있었던 3명의 환자 모두에서 시술한 쪽의 뇌관류 예비능이 증가되었다(Table 2). 시술한 쪽과 반대쪽에도 내경동맥 에 협착이나 폐색이 있었던 환자 4 명중에서는 3명에서 시술한 쪽 뇌관류예비능이 증가되었다(Table 3).

\section{2. 파워스펙트럼 변화}

1) 아세타졸라마이드를 주사하기 전의 뇌파

한 쪽에만 경동맥협착이 있었던 3명에서는 시술 전에 협착이 있
는 반구의 파워스펙트럼비가 반대쪽 보다 모두 감소되어 있었다. 시술 후에는 시술한 쪽 대뇌반구에서 파워스펙트럼비가 모두 증가 하였다(Table 2).

반대쪽에도 협착이 있었던 환자 4 명중에서는 3명에서 시술 전 에 협착이 있는 반구의 파워스펙트럼비가 반대쪽 보다 감소되어 있 었다. 시술 후에는 3 명에서 시술한 쪽 대뇌반구에서 파워스펙트럼 비가 증가하였다(Table 3).

\section{2) 아세타졸라마이드를 주사한 후의 뇌파}

한 쪽에만 경동맥협착이 있었던 3명에서는 시술 전에 협착이 있 는 반구의 파워스펙트럼비가 반대쪽 보다 모두 감소되어 있었다. 시술 후에는 3 명중 2 명에서 파워스펙트럼비가 시술한 쪽 대뇌반구 에서 증가하였다(Table 2).

반대쪽에도 협착이 있었던 환자 4 명중에서는 3명에서 시술 전 
Table 3. Spectral ratios in the patients with bilateral stenoses: correlation with the increases of blood-flow reserve in the hemisphere with carotid-artery stenting

\begin{tabular}{|c|c|c|c|c|c|c|}
\hline \multirow{2}{*}{ Patient number } & \multirow{2}{*}{$\begin{array}{l}\text { EEGs according to } \\
\text { ACZ injection }\end{array}$} & \multicolumn{2}{|c|}{ SR of $\mathrm{H}-\mathrm{CAS}$} & \multicolumn{2}{|c|}{ SR of $\mathrm{H}-\mathrm{No}$} & \multirow{2}{*}{$\begin{array}{l}\text { Increase of blood-flow } \\
\text { reserve in CAS-H }\end{array}$} \\
\hline & & Pre-stent* & Post-stent $^{\dagger}$ & Pre-stent & Post-stent & \\
\hline \multirow[t]{2}{*}{5} & Pre-ACZ ${ }^{\dagger}$ & 1.04 & 2.41 & 1.06 & 2.69 & Yes \\
\hline & Post-ACZ & 1.11 & 3.42 & 1.29 & 2.51 & \\
\hline \multirow[t]{2}{*}{7} & Pre-ACZ & 2.15 & 2.46 & 1.49 & 1.77 & No \\
\hline & Post-ACZ & 2.24 & 1.35 & 1.63 & 0.73 & \\
\hline \multirow[t]{2}{*}{10} & Pre-ACZ & 2.61 & 2.94 & 3.11 & 5.13 & Yes \\
\hline & Post-ACZ & 2.49 & 2.49 & 2.85 & 4.06 & \\
\hline \multirow[t]{2}{*}{16} & Pre-ACZ & 3.16 & 1.76 & 3.32 & 3.07 & Yes \\
\hline & Post-ACZ & 2.45 & 1.44 & 2.84 & 2.56 & \\
\hline
\end{tabular}

\footnotetext{
*Baseline time point.

† 1 month after carotid artery stenting.

† The time point just before injection of acetazolamide.

${ }^{\S}$ The time point just after the acetazolamide-SPECT study.

Abbreviation: See Table 2.
}

Table 4. Interhemispheric index of spectral ratio in the patients with unilateral stenosis: correlation with the increases of blood-flow reserve in the hemisphere with carotid-artery stenting

\begin{tabular}{|c|c|c|c|c|c|}
\hline \multirow{2}{*}{ Patient number } & \multirow{2}{*}{$\begin{array}{l}\text { EEGs according to } \\
\text { ACZ injection }\end{array}$} & \multicolumn{2}{|c|}{ IHISR } & \multirow{2}{*}{$\triangle \mathrm{IHISR}(\%)$} & \multirow{2}{*}{$\begin{array}{l}\text { Increase of blood-flow } \\
\text { reserve in CAS-H }\end{array}$} \\
\hline & & Pre-stent* & Post-stent $^{\dagger}$ & & \\
\hline \multirow[t]{2}{*}{2} & Pre-ACZ $^{\ddagger}$ & 0.49 & 0.45 & -7.13 & Yes \\
\hline & Post-ACZ ${ }^{\S}$ & 0.46 & 0.50 & 8.18 & \\
\hline \multirow[t]{2}{*}{3} & Pre-ACZ & 0.45 & 0.50 & 11.20 & Yes \\
\hline & Post-ACZ & 0.48 & 0.50 & 4.28 & \\
\hline \multirow[t]{2}{*}{13} & Pre-ACZ & 0.26 & 0.48 & 46.78 & Yes \\
\hline & Post-ACZ & 0.29 & 0.44 & 34.50 & \\
\hline
\end{tabular}

*Baseline time point.

${ }^{\dagger} 1$ month after carotid artery stenting.

${ }^{\ddagger}$ The time point just before injection of acetazolamide.

${ }^{\S}$ The time point just after the acetazolamide-SPECT study.

Abbreviation: IHISR, interhemispheric index of spectral ratio; H-CAS, hemisphere with carotid-artery stenting; $\triangle$ IHISR, percent difference of IHISRs between IHISR 1 month after carotid-artery stenting and IHISR just before carotid-artery stenting.

에 시술한 쪽 파워스펙트럼비가 반대쪽에 비하여 감소되어 되었다. 시술을 한 후에는 시술 전과 비교시 4 명중 1 명에서만 파워스펙트 럼비가 증가하였다(Table 3).

\section{3. 반구인덱스의 변화}

\section{1) 아세타졸라마이드를 주사하기 전의 뇌파}

한쪽협착 3 명중 2 명의 환자에서 반구인덱스비가 시술 후에 증 가되었다. 나머지 한명에서는 반구인덱스비가 감소하였다(Table 4). 양쪽협착 4명 모두에서는 시술 후에 반구인덱스비가 감소하였 다(Table 5). 시술 전후의 반구인덱스차이는 각 환자마다 다양하였 으며 Table 4와 Table 5에 기술하였다.

\section{2) 아세타졸라마이드를 주사한 후의 뇌파}

한쪽협착 3 명의 환자 모두에서는 반구인덱스가 시술 전에 비해
시술 후에 증가하였다(Table 4). 양쪽협착 4명 중 2명에서는 시술 전에 비해 시술 후에 반구인덱스가 증가하였고 나머지 2명에서는 감소하였다(Table 5). 시술 전후의 반구인덱스차이는 각 환자마다 다양하였으며 Table 4와 Table 5에 기술하였다.

\section{4. 뇌파분석결과와 뇌관류예비능과의 연관성}

한쪽협착 환자 3 명에서 모두 호전된 뇌파분석의 결과는 아세타 졸라마이드 주사전의 파워스펙트럼비와 아세타졸라마이드 주사 후의 반구인덱스비였다. 이 3 명의 환자 모두에서 시술 후에 시술한 대뇌반구에 뇌관류예비능이 증가하였다(Table 2, Table 4).

양쪽협착 환자 4 명에서는 뇌파분석의 결과에서 일정한 양상이 없었고 뇌관류예비능과도 연관성을 찾기가 힘들었다. 환자 5 의 예 를 들어보면 뇌관류예비능이 시술 후에 증가하기는 했지만 시술 전 의 파워스펙트럼비가 반대쪽 보다 높았고 시술 후에 아세타졸라마 
Table 5. Interhemispheric index of spectral ratio in the patients with bilateral stenoses: correlation with the increases of blood-flow reserve in the hemisphere with carotid-artery stenting

\begin{tabular}{|c|c|c|c|c|c|}
\hline \multirow{2}{*}{ Patient number } & \multirow{2}{*}{$\begin{array}{l}\text { EEGs in each time } \\
\text { point of } A C Z \text { injection }\end{array}$} & \multicolumn{2}{|c|}{ IHISR } & \multirow{2}{*}{$\Delta \mathrm{IHISR}(\%)$} & \multirow{2}{*}{$\begin{array}{l}\text { Increase of blood-flow } \\
\text { reserve in CAS-H }\end{array}$} \\
\hline & & Pre-stent* & Post-stent $^{\dagger}$ & & \\
\hline \multirow[t]{2}{*}{5} & Pre-ACZ ${ }^{\ddagger}$ & 0.50 & 0.47 & -4.93 & Yes \\
\hline & Post-ACZ ${ }^{\S}$ & 0.46 & 0.58 & 20.02 & \\
\hline \multirow[t]{2}{*}{7} & Pre-ACZ & 0.59 & 0.58 & -1.55 & No \\
\hline & Post-ACZ & 0.58 & 0.65 & 10.80 & \\
\hline \multirow[t]{2}{*}{10} & Pre-ACZ & 0.46 & 0.36 & -5.22 & Yes \\
\hline & Post-ACZ & 0.47 & 0.38 & -22.59 & \\
\hline \multirow[t]{2}{*}{16} & Pre-ACZ & 0.49 & 0.37 & -3.58 & Yes \\
\hline & Post-ACZ & 0.46 & 0.36 & -28.55 & \\
\hline
\end{tabular}

\footnotetext{
*Baseline time point.

+1 month after carotid artery stenting.

${ }^{\ddagger}$ The time point just before injection of acetazolamide.

${ }^{\S}$ The time point just after the acetazolamide-SPECT study.
}

이드 주사 후의 뇌파에서 파워스펙트럼비와 아세타졸라마이드 주 사후 반구인덱스비가 감소하였다(Table 3, Table 5).

\section{고 찰}

저자들은 두개외경동맥협착이 있는 환자에서 경동맥스텐트삽 입술을 하였다. 이 환자들에게 뇌SPECT-감산영상 촬영과 뇌파 검 사를 시술직전과 시술 후 한 달이 경과한 시점에서 시행하여 경동 맥스텐트삽입술로 변화한 뇌관류예비능을 관찰하고 뇌파파워스 펙트럼분석과의 연관성을 살펴보았다. 경동맥협착이 한쪽에만 있 었던 환자들은 모두 시술 후에 같은 쪽 뇌반구에 뇌관류예비능이 증가하였고 아세타졸라마이드 주사전의 스펙트럼비와 아세타졸 라마이드 주사 후의 반구인덱스비도 세명 모두에서 증가하여 이 두 가지 수치가 뇌관류예비능을 가장 잘 반영하였다. 일상적으로 뇌파 를 검사할 때 아세타졸라마이드를 정주하는 일은 거의 없으므로, 아세타졸라마이드 주사전의 스펙트럼비가 뇌관류예비능을 잘 반 영하였다는 점은 평상시 하는 뇌파검사로 경동맥스텐트삽입술의 효과를 평가할 수 있을 가능성을 제시해 준다. 이는 뇌파검사가 뇌 혈관예비능을 평가하는데 편리성과 유용성을 같이 가지고 있을 수 있다는 것이다. 시술한 반대쪽 뇌에도 경동맥의 폐쇄나 협착이 있 던 환자들의 뇌관류예비능과 뇌파분석의 수치는 다양하였다. 따라 서 양쪽 경동맥의 이상이 있는 경우는 경동맥스텐트삽입술 후 뇌혈 류예비능을 뇌파의 파워스펙트럼분석으로 추정하기는 어려웠다. 추정이 어려운 이유는 양쪽에 협착이 있는 경우에는 곁순환이 다양 한 형태로 발달하고 뇌혈류의 혈역학이 복잡해 지기 때문인 것으로 판단하였다.

뇌는 자체적인 에너지 저장 능력이 매우 낮아 혈류를 통한 산소 와 포도당의 지속적인 공급이 요구되며 일시적으로 혈류가 차단되
어도 뇌는 민감하게 반응하여 신경활동에 지장이 생긴다[14]. 경동 맥내막절제술 중 경동맥을 결찰하면 즉시 뇌파의 진폭이 $50 \%$ 이상 감쇄하기도 하며[9], 느린파가 발생한다. 느린파는 뇌혈류의 양에 따라 단계적으로 나타나는데 뇌혈류량이 $30 \mathrm{~mL} / 100 \mathrm{mg} / \mathrm{min}$ 이 상에서는 뇌파 변화가 없으나 $16 \sim 22 \mathrm{~mL} / 100 \mathrm{mg} / \mathrm{min}$ 이하로 저 하될 경우 느린파가 나타나며 $11 \sim 19 \mathrm{~mL} / 100 \mathrm{~g} / \mathrm{min}$ 이하의 경우 뇌파의 신호가 없어진다[15]. 뇌혈류량이 증가하는 경우에는 해당 부위에 알파파가 증가하며 델타파가 감소한다[16]. 파워스펙트럼 분석은 빠른푸리에변환을 이용하여 시간에 따른 진폭변화를 주파 수에 따른 진폭의 변화로 값을 수치화하여 정량분석을 가능하게 하 는 방법이다. 이를 이용하면 뇌파와 뇌혈류량과 대사의 상관관계를 정량적으로 분석할 수 있다[17,18].

경동맥스텐트삽입술 전후의 혈류변화와 기능적 변화는 곁순환 을 포함한 다양한 혈역학 환경에 영향을 받기 때문에 한쪽 반구 안 에서 파워스펙트럼비의 변화로 의미를 모두 파악할 수는 없다. 이 문제를 해결하기 위해 본 연구에서는 반구인덱스를 정의하였다. 반 구인덱스는 양쪽 반구의 파워스펙트럼비의 상대적 비율을 구한 것 이다. 즉, 반구인덱스를 통해 양쪽 반구에서 빠른파형군과 느린파 형군의 상대비를 알아볼 수 있으며 시술 전후의 반구간스펙트럼인 덱스의 변화를 통해 반구의 활성이 증가 혹은 감소 되었는지 확인 할 수 있다. 양쪽 뇌의 활성이 같으면 반구인덱스가 0.5 이다. 시술 전 반구인덱스의 경우 7 명의 환자 중 5 명에서 경동맥스텐트를 시 술하게 되는 쪽의 반구의 수치가 0.5 보다 적었다. 경동맥스텐트삽 입술 이후에 반구인덱스가 증가하는 것은 빠른 파형의 파워스펙트 럼이 경동맥스텐트를 삽입한 후에 반대쪽 반구에 비해 많이 증가하 였고 뇌의 활동의 활발해 졌다는 의미이다[16]. 이번 연구에서는 한 쪽의 경동맥협착군에서는 경동맥스텐트를 삽입한 후에 일관성 있 게 반구인덱스가 증가하였다. 아세타졸라마이드 주사 후에는 반구 
인덱스가 3 명 모두에서 증가하였고, 아세타졸라마이드 주사 전의 뇌파에서는 반구인덱스가 3 명중 2 명에서 증가하였다.

뇌관류예비능은 국소뇌혈류를 일정하게 유지하는 자동조절기 능에 관여한다. 아세타졸라마이드를 투여하기 전과 후에 뇌SPECT 를 촬영하여 뇌관류예비능을 평가할 수 있다. 뇌관류예비능은 내경 동맥의 협착에 영향을 많이 받지만 곁순환도 중요한 역할을 한다 [19]. 더구나 동맥이 폐쇄되어 뇌관류예비능이 감소된 환자들에게 우회로술이 도움이 된다[20-22]. 따라서 뇌관류예비능을 관찰하 여 경동맥스텐트삽입술의 치료적 효과를 평가할 수도 있을 것이다. 본 연구에서는 7명의 환자 중 6명의 환자에서는 경동맥스텐트를 삽입한 쪽의 뇌관류예비능이 호전되었으나 한 명에서는 이러한 호 전이 없었다. 한 쪽의 협착이 있었던 3 명의 환자에서는 모두 뇌관류 예비능이 호전되는데 비해 양쪽의 협착 혹은 폐색이 있었던 4 명에 서는 3 명에서만 뇌관류예비능이 호전되었다. 경동맥협착이 있는 경우 단순히 한 쪽의 경동맥이 같은 쪽 반구뿐 아니라 반대쪽 반구 에도 혈류를 제공한다. 대뇌동맥륜와 곁순환에 의해서 혈류가 재분 배되기 때문이다. 특히 양쪽 협착이 있는 경우는 곁순환을 파악하 면 환자의 예후를 판단하는데 도움이 된다[23]. 본 연구에서 양쪽에 협착이 있는 1 명의 환자에서 뇌관류예비능이 증가하지 않은 것과 뇌파분석결과와도 일치도가 떨어진 이유도 혈류 양쪽의 뇌반구에 혈류를 재분배하는 방식이 다양하기 때문일 것이다.

경동맥스텐트삽입술은 자주 하는 시술이 아니기 때문에 환자 모 집에 어려움이 있어서 본 연구에서는 대상 환자를 늘리기가 힘들었 다. 따라서 본 연구를 통해서 경동맥협착 교정 후 뇌파상의 변화는 관찰할 수 있었으나 환자의 수가 적어 통계적인 의의를 얻을 수는 없었다. 또한 한 쪽의 경동맥협착뿐만 아니라 반대쪽 뇌혈관의 협 착이나 폐색이 있는 환자들도 연구에 포함된 것도 결과의 해석에 어려움을 초래하였다. 양쪽 경동맥협착이 있는 환자군에서 경동맥 스텐트삽입술을 하지 않은 쪽의 협착 정도나 위치가 다양하여 결과 해석에 어려움이 있었다. 특히 양측 협착에 따른 곁순환 발달을 평 가하기가 어려웠다. 추후 장기적 연구 계획을 가지고 한쪽 경동맥 협착만 있는 환자를 다수 모집하여 연구를 진행할 필요가 있을 것 이다. 뇌SPECT를 통한 뇌관류예비능을 분석할 여건이 되어 주관 적으로 판단한 것도 본 연구에는 제한점이 되었다. 뇌관류예비능의 변화를 뇌SPECT-감산영상을 통한 단순 시각적 비교를 하였는데, 뇌SPECT 결과를 수치화 하여 분석하는 방법이 접목되면 더욱 의미 가 있을 것이다.

저자들은 본 연구를 통해서 내경동맥협착의 교정은 혈역학적으 로 뇌관류예비능을 증가시키며 이를 통해 장기적인 뇌의 전기생리 학적 변화도 유도할 수 있다는 것을 알 수 있었다. 양쪽 경동맥의 이 상이 있는 경우는 혈역학적 변화가 다양하게 나타날 수 있기 때문
에 경동맥스텐트를 삽입한 쪽의 뇌반구에서 반드시 뇌관류예비능 이 증가되지 않았다. 따라서 경동맥에 스텐트를 삽입하는 반대쪽 뇌혈관에도 협착이나 폐쇄가 있는 경우에서는 경동맥스텐트설치 술 이후의 뇌혈역학 변화에 의한 뇌기능의 변화를 뇌파파워스펙트 럼을 통해 추정하기가 어렵다고 판단하였다. 하지만 경동맥협착이 한 쪽에만 있는 경우에는 뇌파 파워스펙트럼분석이 뇌관류예비능 향상을 예측할 수 있을 가능성이 클 것이다.

\section{요 약}

경동맥경화증은 대뇌혈류를 감소시킬 수 있고, 대뇌신경세포의 활성도에 영향을 미칠 수 있다. 저자들은 경동맥스텐트삽입술 (carotid-artery stenting, CAS) 후 뇌혈류예비능의 회복이 뇌파의 파워스펙트럼에 미치는 영향을 조사하였다. 우선 19명의 CAS 대 상자들을 모집하였다. SPECT의 subtraction imaging과 뇌파를 두 번의 시기에 검사하였다. 두 번의 시기는 CAS 시술 직전과 시술 하고 1 개월이 지난 시점이었다. EEG는 acetazolamide 주입 전 (pre-ACZ EEG)과 주입 후(pre-ACZ EEG)에 기록하였다. 검사를 모두 하지 못했거나 뇌파기록의 질이 분석에 적절하지 못했던 환자 를 제외하고 최종적으로 7 명의 환자를 대상으로 연구하였다. 저자 들은 각각의 대뇌 반구에서 spectral ratio (SR)를 구했다. SR은 빠 른파형의 파워스펙트럼 수치를 느린파형의 파워스펙트럼 수치로 나눈 값으로 정의하였다. 또한 저자들은 저자들은 반구간인덱스 (inter-hemispheric index of spectral ratio, IHISR)를 이용하여 양쪽 대뇌 반구 사이의 파워스펙트럼 수치를 비교하였고, 파워스 펙트럼의 변화와 뇌혈류예비능의 변화 사이의 연관성을 관찰하였 다. 총 7명의 환자 중 6명의 환자에서 CAS 시행 후스텐트를 삽입한 쪽의 뇌혈류예비능이 호전되었다. 편측 경동맥경화증이 있었던 3 명의 환자들에서는 모든 환자에서 CAS가 pre-ACZ EEG에서 SR을 증가시켰고, post-ACZ EEG의 IHISR을 증가시켰다. SR과 IHISR 의 증가는 뇌혈류예비능의 증가와 연관성이 있었다. 반면에 양쪽 경동맥경화증이 있었던 나머지 환자들의 결과는 복잡한 양상을 띄 었다. 경동맥협착증이 한쪽에만 있는 환자에서 pre-ACZ EEG의 SR과 post-ACZ EEG의 IHISR가 CAS를 시술한 후에 뇌혈류예비 능의 변화를 평가할 수 있는 유용한 전기생리학적 지표가 될 수 있 다는 것을 본 연구의 결과를 통해 알 수 있었다. 그러나 경동맥협착 증이 양쪽 모두에 있었던 환자들에서는 결과가 복잡한 양상으로 나 타났다. 이는 양쪽 협착이 있는 경우에는 뇌의 혈역학이 복잡하기 때문일 것으로 판단하였다. 


\author{
Acknowledgements: None \\ Funding: None \\ Conflict of interest: None
}

\section{References}

1. Matsuda H, Higashi S, Kinuya K, Tsuji S, Nozaki J, Sumiya H, et al. SPECT evaluation of brain perfusion reserve by the acetazolamide test using Tc-99m HMPAO. Clin Nucl Med. 1991; 16(8):572-579.

2. Kuroda S, Houkin K, Kamiyama H, Mitsumori K, Iwasaki Y, Abe H. Long-term prognosis of medically treated patients with internal carotid or middle cerebral artery occlusion: can acetazolamide test predict it? Stroke. 2001;32(9):2110-2116.

3. Vernieri F, Pasqualetti P, Passarelli F, Rossini PM, Silvestrini M. Outcome of carotid artery occlusion is predicted by cerebrovascular reactivity. Stroke. 1999;30(3):593-598.

4. Vagal AS, Leach JL, Fernandez-Ulloa M, Zuccarello M. The acetazolamide challenge: techniques and applications in the evaluation of chronic cerebral ischemia. AJNR Am J Neuroradiol. 2009;30(5):876-884.

5. Derdeyn CP. Is the acetazolamide test valid for quantitative assessment of maximal cerebral autoregulatory vasodilation? Stroke. 2000;31(9):2271-2272.

6. Trojaborg W, Boysen G. Relation between EEG, regional cerebral blood flow and internal carotid artery pressure during carotid endarterectomy. Electroencephalogr Clin Neurophysiol. 1973;34(1):61-69.

7. Whittemore AD, Kauffman JL, Kohler TR, Mannick JA. Routine electroencephalographic (EEG) monitoring during carotid endarterectomy. Ann Surg. 1983;197(6):707-713.

8. Myers RR, Stockard JJ, Saidman LJ. Monitoring of cerebral perfusion during anesthesia by time-compressed Fourier analysis of the electroencephalogram. Stroke. 1977;8(3):331-337.

9. Chiappa KH, Burke SR, Young RR. Results of electroencephalographic monitoring during 367 carotid endarterectomies. Use of a dedicated minicomputer. Stroke. 1979;10(4):381-388.

10. Shin WC HE, Hyung KL, Kang HO, Lee TG, Chang DI, et al. Decision of shunt insertion based on electroencephalography and stump pressure during carotid endarterectomy. J Korean Neurol Assoc. 1999;17(6):797-803.

11. Kluytmans M, van der Grond J, Viergever MA. Gray matter and white matter perfusion imaging in patients with severe carotid artery lesions. Radiology. 1998;209(3):675-682.

12. van Laar PJ, van der Grond J, Moll FL, Mali WP, Hendrikse J.
Hemodynamic effect of carotid stenting and carotid endarterectomy. J Vasc Surg. 2006;44(1):73-78.

13. North American Symptomatic Carotid Endarterectomy Trial (NASCET) investigators. Clinical alert: benefit of carotid endarterectomy for patients with high-grade stenosis of the internal carotid artery. National Institute of Neurological Disorders and Stroke Stroke and Trauma Division. Stroke. 1991;22(6):816817.

14. Ihl R, Eilles C, Frlich L, Maurer K, Dierks T, Perisic I. Electrical brain activity and cerebral blood flow in dementia of the Alzheimer type. Psychiatry Res. 1989;29(3):449-452.

15. Sharbrough FW, Messick JM Jr., Sundt TM Jr. Correlation of continuous electroencephalograms with cerebral blood flow measurements during carotid endarterectomy. Stroke. 1973; 4(4):674-683.

16. Nagata K. Topographic EEG in brain ischemia--correlation with blood flow and metabolism. Brain Topogr. 1988;1(2): 97-106.

17. Nagata K, Gross CE, Kindt GW, Geier JM, Adey GR. Topographic electroencephalographic study with power ratio index mapping in patients with malignant brain tumors. Neurosurgery. 1985;17(4):613-619.

18. Nagata K, Tagawa K, Hiroi S, Shishido F, Uemura K. Electroencephalographic correlates of blood flow and oxygen metabolism provided by positron emission tomography in patients with cerebral infarction. Electroencephalogr Clin Neurophysiol. 1989;72(1):16-30.

19. Hosoda K, Fujita S, Kawaguchi T, Shose Y, Shibata Y, Tamaki N. Influence of degree of carotid artery stenosis and collateral pathways and effect of carotid endarterectomy on cerebral vasoreactivity. Neurosurgery. 1998;42(5):988-994.

20. Muraishi K, Kameyama M, Sato K, Sirane R, Ogawa A, Yoshimoto T, et al. Cerebral circulatory and metabolic changes following EC/IC bypass surgery in cerebral occlusive diseases. Neurol Res. 1993;15(2):97-103.

21. Yasui N, Suzuki A, Sayama I, Kawamura S, Shishido F, Uemura K. Comparison of the clinical results of STA-MCA anastomosis and the medical treatment in the cerebral low perfusion patients with viable brain tissue. Neurol Res. 1991;13(2):84-88.

22. Piepgras A, Leinsinger G, Kirsch CM, Schmiedek P. STA-MCA bypass in bilateral carotid artery occlusion: clinical results and long-term effect on cerebrovascular reserve capacity. Neurol Res. 1994;16(2):104-107.

23. Romero JR, Pikula A, Nguyen TN, Nien YL, Norbash A, Babikian VL. Cerebral collateral circulation in carotid artery disease. Curr Cardiol Rev. 2009;5(4):279-288. 